\title{
The histology and in vivo sulphate uptake of epiphyseal cartilage in protein-depleted rats
}

\author{
BY B. SHAPIRO AND B. PIMSTONE* \\ Isotope and Immunoassay Laboratory, Department of Medicine, \\ University of Cape Town Medical School, \\ Observatory 7925, South Africa
}

(Received 28 February 1977 - Accepted 23 March 1977)

1. Weanling rats, aged $21 \mathrm{~d}$, given a $40 \mathrm{~g}$ casein $/ \mathrm{kg}$ diet for $25 \mathrm{~d}$ were compared with 'age-matched' controls given a $200 \mathrm{~g}$ casein $/ \mathrm{kg}$ diet and with 'weight-matched' weanling controls.

2. The protein-malnourished rats demonstrated failure of weight gain and linear growth, hypoproteinaemia, hypoalbuminaemia and fatty liver.

3. Autoradiography of the tibia was carried out $24 \mathrm{~h}$ after intraperitoneal injection of $\mathrm{Na}_{2}{ }^{35} \mathrm{SO}_{4}(0 \cdot 1$, $1 \cdot 0,2 \cdot 0,5,10 \mu \mathrm{Ci} / \mathrm{g}$ body-weight). Sections of tibia, humerus and costochondral junction were stained by haematoxylin and eosin, resorcin-crystal violet and picro-fuchsin, Alcian Blue at $\mathrm{pH} 0.1$ and $\mathrm{pH} 2.5$, Alcian Blue at pH 5.7 with magnesium chloride $(0.1,0.7,1.0 \mathrm{M})$, and by Alcian Blue after ovine testicular hyaluronidase $(E C 3.2 .1 .35)$ digestion.T he width of the upper tibial epiphysis was measured and the histological and histochemical features of the epiphyses studied.

4. The incorporation of ${ }^{35} \mathrm{SO}_{4}$ into the epiphyses of the protein-malnourished animals was markedly reduced. The chondrocytes were small and flattened with frequent pyknotic nuclei. The staining characteristics of the cartilagenous matrix was qualitatively similar in all animals. The epiphyses in malnutrition were found to be thin, all zones being affected. The upper tibial epiphyses (mean \pm SD; $\mu \mathrm{m}$ ) were $202 \pm 46$ for the protein-malnourished animals, $367 \pm 52$ for age-matched controls and $578 \pm 40$ for weight-matched controls.

5. The changes found resemble those after hypophysectomy and the possible hormonal factors are discussed.

Failure to grow is a striking feature of protein malnutrition; this applies both to weight gain and skeletal growth (Berridge \& Prior, 1954; Trowell, Davies \& Dean, 1954). As the linear growth of long bones, which is the main contributor to height in man, occurs at the epiphysis (Davies \& Coupland, 1967), we have chosen to study the epiphyseal growth plates of rats subjected to a well-validated regimen producing protein malnutrition (Stead \& Brock, 1972) to elucidate the morphological features of this phenomenon. To date, epiphyseal cartilage in malnutrition has not been studied by in vivo sulphate uptake, nor have the staining characteristics of the matrix been determined by a wide range of histochemical techniques.

\section{METHODS}

The animal model. The experimental model used was based on that of Stead \& Brock (1972). Unsexed Wistar weanlings (age $21 \mathrm{~d}$, weight $30-40 \mathrm{~g}$ ) were housed in mesh-bottomed stainless-steel cages in an air-conditioned room $\left(18-20^{\circ}\right)$ with a $12 \mathrm{~h}$ light-12 h dark cycle. They were allowed free access to one of two diets: $200 \mathrm{~g}$ protein in the form of casein $/ \mathrm{kg}$, or $40 \mathrm{~g}$ casein $/ \mathrm{kg}$ supplemented with $2 \mathrm{~g}$ DL-methionine $/ \mathrm{kg}$. Both diets were isoenergetic and provided known and adequate amounts of vitamins, minerals and trace elements (Harper, 1959). The rats given the $200 \mathrm{~g}$ protein $/ \mathrm{kg}$ diet acted as 'age-matched' controls for those on the $40 \mathrm{~g}$ protein $/ \mathrm{kg}$ diet, while untreated weanlings acted as 'weight-matched' controls. The experimental diet was fed for $25 \mathrm{~d}$.

All animals were weighed twice weekly and the length of tail and total length (from

* For reprints. 
nose to tail tip) measured at the beginning and end of the period on the experimental diet.

Validation of the model. Total serum protein was determined by the method of Lowry, Rosebrough, Farr \& Randall (1951) and serum albumin by that of Doumas, Watson \& Biggs (1971). Liver fat was measured by the decrease in the weight of the dried liver after extraction with light petroleum (b.p. 40-60') (Hazlewood \& Nichols, 1969) and expressed as a proportion of the unextracted dry liver weight. Liver histology was carried out on $10 \mu \mathrm{m}$ frozen sections of tissue fixed in buffered formalin, $\mathrm{pH} 7 \cdot 3$, and stained with Oil Red O in propan-2-ol (Lillie \& Ashburn, 1943) and Mayer's haematoxylin and eosin.

In vivo sulphate uptake into cartilage. Carrier-free $\mathrm{Na}_{2}{ }^{35} \mathrm{SO}_{4}$ (The Radiochemical Centre, Amersham, Bucks., UK) was diluted in sterile physiological saline ( $9 \mathrm{~g}$ sodium chloride/l) and was administered by intraperitoneal injection at six dosages $(0,0 \cdot 1,1,2,5,10 \mu \mathrm{Ci} / \mathrm{g}$ body-weight) in $1 \mathrm{ml}$ saline. Animals were killed by exsanguination under light diethyl ether anaesthesia. The tibias with intact knee and ankle joints were dissected free of most attached muscle. In five animals from each group the costochondral junctions of the 7th rib and the humerus with intact shoulder and elbow joints were similarly dissected. All tissue was fixed in formalin with $0.015 \mathrm{M}$-cetylpyridinium chloride (Engfeldt \& Hjertquist, 1967) for $24 \mathrm{~h}$ and decalcified in formalin with $1.1 \mathrm{M}$-formic acid for $72 \mathrm{~h}$. The decalcified bones were then bisected (equal numbers in the saggital or coronal planes), dehydrated in graded alcohols, cleared in xylol and embedded in paraffin wax. Multiple sections $8 \mu \mathrm{m}$ thick were cut from each block and dewaxed. Autoradiography was carried out by a modification of the method of Dziewiatkowski (1951), sections were placed in direct contact with the emulsion of film (Kodak Ortho Process Film Strips $(20 \times 60 \mathrm{~mm})$; Eastman Kodak Co., Rochester, New York, USA). After periods ranging from 5 to $40 \mathrm{~d}$ the film was developed and fixed as originally described.

Cartilage histochemistry. Tissue removed from contact with the film was stained with Mayer's haemalum and eosin for cellular morphology; the resorcin-crystal violet and picro-fuchsin method of Sweet (1968) which stained chondroitin sulphate pale blue and keratosulphate pink; Alcian Blue, $8 \mathrm{~mm}$ in $0.1 \mathrm{M}$-hydrochloric acid ( $\mathrm{pH} 1.0)$, for sulphated mucopolysaccharides; Alcian Blue, $8 \mathrm{~mm}$ in $0.5 \mathrm{M}$-acetic acid ( $\mathrm{pH} \mathrm{2.5)}$, for carboxyl and sulphate groups of mucopolysaccharides (Culling, 1974); Alcian Blue, $8 \mathrm{~mm}$ in $0 \cdot 1 \mathrm{M}$-acetate buffer (pH 5.7) with magnesium chloride at $0 \cdot 1,0 \cdot 7$ and $1.0 \mathrm{M}$, according to the critical electrolyte concentration method of Quintarelli, Scott \& Dellovo (1964), for differentiating acid from sulphated mucopolysaccharides. Some sections were subjected to ovine testicular hyaluronidase (EC 3.2.1.35) digestion before staining with Alcian Blue, $8 \mathrm{~mm}$ in $0 \cdot 1 \mathrm{M}-\mathrm{HCl}$ (Culling, 1974). All sections were dehydrated in graded alcohols cleared in xylol and mounted in Gurr Depex (Searle Diagnostic, High Wycombe, Bucks., UK).

Tibial length and epiphyseal width. Tibial lengths were measured with a transparent rule and the width of the upper tibial epiphysis in its central half at five equidistant points by eyepiece micrometer on at least five sections from each tibia. All sections and autoradiographs were assigned a random number and examined and measured without the observer having any knowledge of the group of animals from which they were derived.

\section{RESULTS}

Experimental model. In all respects the experimental animals conformed closely to those of Stead \& Brock (1972) with failure of weight gain, hypoproteinaemia, hypoalbuminaemia and fatty liver (Table 1).

Tibial epiphyseal width. Micrometric measurement of tibial epiphyseal autoradiographs and stained sections showed those of the protein-malnourished rats to be significantly 


\section{Table 1. Morphological and biochemical features of protein-deficient and 'age-' and 'weight-matched' control rats}

(Mean values and standard deviations for twenty rats/treatment)

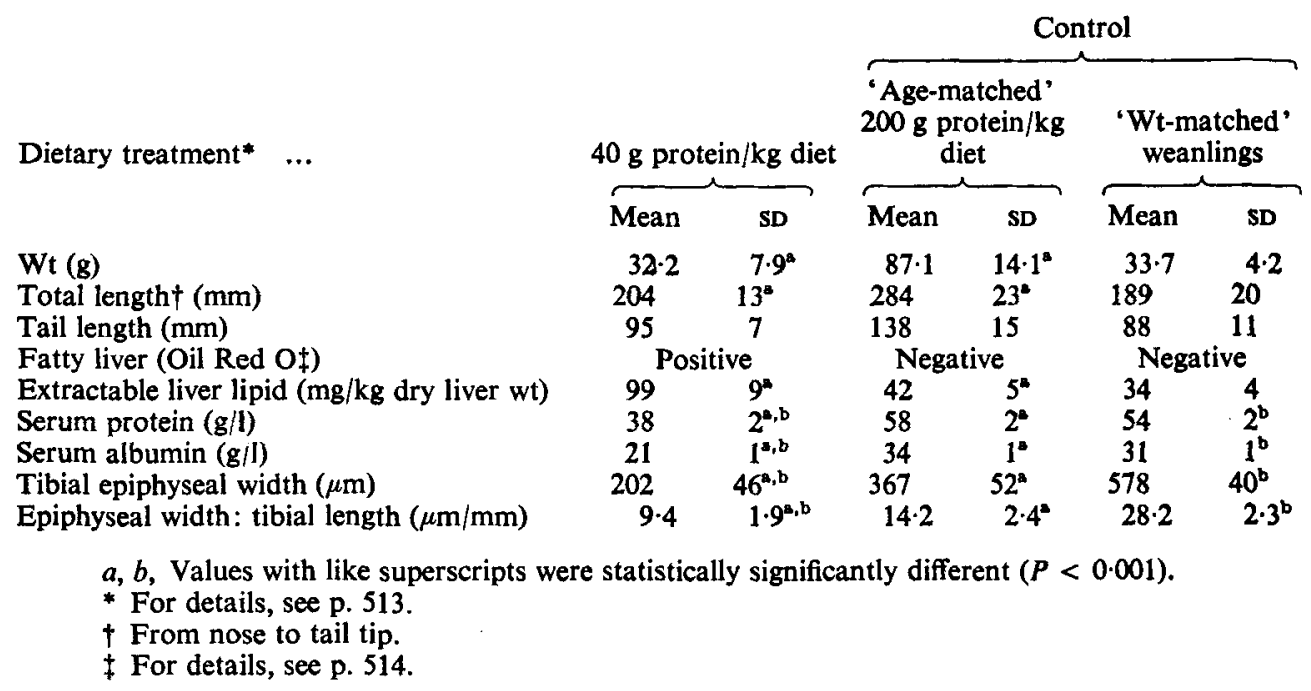

narrower than either 'age-' or 'weight-matched' controls whether expressed as absolute width or relative to total bone length (Table 1). Similar results were obtained for lower tibial, lower femoral, upper humeral and lower humeral epiphyses but the variance of micrometric measurements was greater.

Histological features. The narrowing of the epiphyseal cartilage plate (Plate 1) was due to a reduction in the thickness of all the zones (resting, proliferating, maturing and degenerating). The proliferating zone was most severely affected. The osteoid tissue and osteoblasts were atrophic. The cartilage cells were small, flattened with frequent pyknotic nuclei. The metaphyseal trabeculae were narrow and poorly branched. There was poor vascular invasion of the metaphyseal-epiphyseal junction.

Histochemistry of cartilage. There was no significant difference in the staining properties of the matrix of the epiphyseal cartilage of the three groups of animals, as studied by the methods detailed previously, suggesting that the acid and sulphated mucopolysaccharides are qualitatively similar as defined by histochemical staining. However, there was quantitatively less of this material in the epiphyses of protein-malnourished rats as the epiphyseal width was far narrower (see Plate 1).

In vivo sulphate uptake. Autoradiographic films showed a striking decrease in the deposition of ${ }^{35} \mathrm{SO}_{4}$ in the cartilage of the protein-malnourished rat. This applied especially to the epiphyseal growth plate but also to the articular cartilage, bone, periosteum and joint capsule (Plate 1). In the instance of costal cartilage maximum uptake was in the cartilage adjacent to the costochondral junction in all groups, but was again least in the protein-malnourished animals. Unlabelled control sections produced no image on the film.

\section{DISCUSSION}

Human protein energy malnutrition (PEM) is heteogeneous in respect of the extent of protein and energy deprivation and in the extent of concomitant vitamin and mineral deficit, water and electrolyte imbalance, infections and infestations. The experimental 
model has the advantage of providing a more homogeneous environment, allowing a more precise study of the role of protein deficiency.

The rat model of protein malnutrition we have used in this study has many features in common with those of human PEM. In many cases of PEM, the period of protein deprivation commences at the time of weaning. In addition, the rats show failure of weight gain and of linear growth, hypoproteinaemia, hypoalbuminaemia, periportal fatty infiltration and increased extractable liver fat. This same model has been previously shown to have abnormal glucose tolerance and insulinopaenia, similar to human PEM (Weinkove, Weinkove \& Pimstone, 1976). Regarding bone metabolism, this model has a lowered exchangeable calcium pool and bone $\mathrm{Ca}$ accretion rate associated with poor $\mathrm{Ca}$ absorption (le Roith \& Pimstone, 1973) and low intestinal Ca-binding protein but normal vitamin D metabolism (Kalk \& Pimstone, 1974) and no vitamin D deficiency (le Roith \& Pimstone, 1973). Poor bone growth and a thin tibial epiphyseal plate had been noted, but not further explored (le Roith \& Pimstone, 1973). The choice of the upper tibial epiphyseal plate for this detailed investigation was because of its uniformity, which in the rat has made this the site of choice for studying epiphyseal growth, as in the bioassays of growth hormone (Evans, Simpson, Marx \& Kibrick, 1943; Greenspan, Li, Simpson \& Evans, 1949). Our findings in all three groups of animals confirm this to be the most uniform and easily studied epiphysis.

Much of the emphasis on the study of the skeleton in protein malnutrition has been directed towards $\mathrm{Ca}$ and bone metabolism rather than that part of the skeleton especially relevant to growth, i.e. the epiphyseal cartilage (Higginson, 1954; Platt \& Stewart, 1962; Deo, Sood \& Ramalingaswami, 1965; Jha, Deo \& Ramalingaswami, 1968; Adams \& Berridge, 1969; Dickerson \& John, 1969; le Roith \& Pimstone, 1973). Where cartilage has been studied it has frequently been that of the costochondral junction rather than that of long bones, and only in the instance of Deo et al. (1965) have any special cartilage stains been used (PAS-Alcian Blue). Our findings in general confirm the narrowing, inactivity and cellular changes previously described. They also show the changes in costochondral-junction and long-bone epiphyseal plates to be essentially the same. The direct measurements of tibial sections are in agreement with the radiographic findings of le Roith \& Pimstone (1973). No significant differences in the nature of the staining of the matrix was found suggesting that the mucopolysaccharides formed were similar in composition but reduced in amount in the instance of protein malnutrition. The changes, oedema and hyalinization, described by Silberberg \& Silberberg (1940) in female guineapigs subjected to over-all food restriction were not observed.

Regarding the choice of autoradiographic methods, fixation in formalin containing cetylpyridinium chloride has been shown to elute the smallest amount of ${ }^{35} \mathrm{SO}_{4}$ containing mucopolysaccharide from cartilage (Engfeldt \& Hjertquist, 1967). The importance of unlabelled controls to exclude spurious images on the film due to direct chemical action has been stressed (Dziewiatkowski, 1951). It has been shown that $24 \mathrm{~h}$ after in vivo labelling with $\mathrm{Na}_{2}{ }^{35} \mathrm{SO}_{4}$, most of the sulphate is incorporated into the mucopolysaccharides of cartilage and very little is free (Boström, 1952; Dziewiatkowski, 1954; Dziewiatkowski, DiFerrante, Bronner \& Okinaka, 1957). The reduced uptake of ${ }^{35} \mathrm{SO}_{4}$ into the tissues of protein-malnourished rat tibias, especially into the epiphyseal growth-plate cartilage, is a functional reflection of the histological evidence of tissue inactivity.

The growth, histology and $\mathrm{Na}_{2}{ }^{35} \mathrm{SO}_{4}$-labelling in vivo and in vitro of cartilage are subject to a variety of hormonal influences. The histological (Freud, Levie \& Kroon, 1939; Ingalls \& Hayes, 1941; Ray, Evans \& Becks, 1941) and autoradiographic (Dziewiatkowski, 1964) features of epiphyseal cartilage in hypophysectomized animals are not dissimilar to our findings and are reversed by growth hormone. It has been shown that growth hormone 


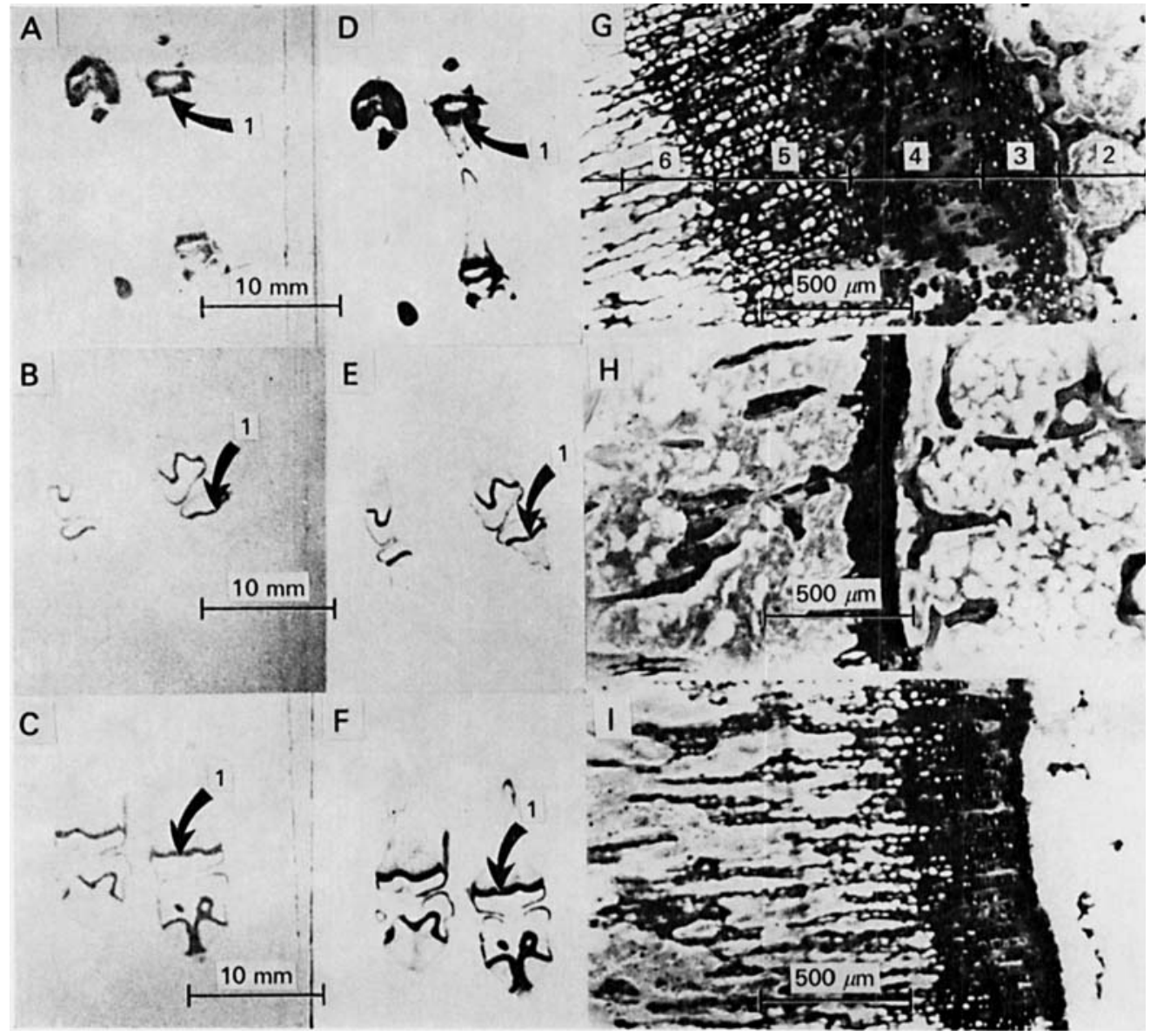


does not act directly on cartilage to stimulate sulphate uptake into mucopolysaccharides but that this activity is mediated by growth hormone-dependent growth factors termed somatomedins (Salmon \& Daughaday, 1957; Chochinov \& Daughaday, 1976). In human PEM, somatomedin has been shown to be low in spite of high growth hormone levels (Grant, Hambley, Becker \& Pimstone, 1973) and in acute starvation in the rat, somatomedin levels are low and unresponsive to pharmacological doses of exogenous growth hormone (Phillips \& Young, 1976). The histological features of an inactive, atrophic epiphyseal growth plate with reduced uptake of $\mathrm{Na}_{2}{ }^{35} \mathrm{SO}_{4}$ into mucopolysaccharide of the matrix which is not histochemically different from normal, probably reflects similarly reduced hormonal stimulation in this experimental model of protein malnutrition, and studies in this connexion are currently underway.

The authors would like to thank Mr Milton Stofile for technical assistance. This study was supported financially by the South African Medical Research Council and Atomic Energy Board, the University of Cape Town Staff Research Fund and the Nellie Atkinson Bequest.

\section{EXPLANATION OF PLATE}

A-C, autoradiography after administration of $\mathrm{Na}_{2}{ }^{35} \mathrm{SO}_{4}(1 \mu \mathrm{Ci} / \mathrm{g}$ body-weight $)$ to protein-deficient and 'age-' and 'weight-matched' control rats $24 \mathrm{~h}$ before slaughter; film exposure $20 \mathrm{~d}$. A, weanling ('weightmatched' controls) marked ${ }^{35} \mathrm{SO}_{4}$ uptake into epiphysis and articular cartilage; $\mathrm{B}$, rats given $40 \mathrm{~g}$ protein $/ \mathrm{kg}$ diet (protein-deficient); poor ${ }^{35} \mathrm{SO}_{4}$ uptake into narrow epiphysis; $\mathrm{C}$, rats given $200 \mathrm{~g}$ protein $/ \mathrm{kg}$ diet, good ${ }^{35} \mathrm{SO}_{4}$ uptake mainly into epiphyseal cartilage. D-I, sections from the three groups of rats were stained with Alcian Blue at $\mathrm{pH} 1.0 ; \mathrm{D}+\mathrm{G}$, weanling, very wide active epiphysis; $\mathrm{E}+\mathrm{H}, 40 \mathrm{~g}$ protein $/ \mathrm{kg}$ diet, narrow atrophic epiphysis; F+I, $200 \mathrm{~g}$ protein $/ \mathrm{kg}$ diet, ('age-matched' controls) wide active epiphysis. Magnification: (A-C) $\times 2$; (D-F) $\times 2 ;(G-I) \times 58$. (1) Upper tibial epiphysis; (2) epiphyseal ossification centre; (3) zone of resting epiphyseal cartilage; (4) zone of proliferating epiphyseal cartilage; (5) zone of maturing epiphyseal cartilage; (6) zone of degenerating epiphyseal cartilage. For details of diets and experimental procedures, see pp. 513-514.

\section{REFERENCES}

Adams, P. \& Berridge, F. R. (1969). Archs Dis. Childh. 44, 705.

Berridge, F. R. \& Prior, K. M. (1954). Spec. Rep. Ser. med. Res. Coun. no. 287, 119.

Boström, H. (1952). J. biol. Chem. 196, 477.

Chochinov, R. H. \& Daughaday, W. H. (1976). Diabetes 25, 994.

Culling, C. F. A. (1974). Handbook of Histopathological and Histochemical Techniques, 3rd ed., pp. $259-314$.

London: Butterworth and Co.

Davies, D. V. \& Coupland, R. E. eds. (1967). Grey's Anatomy, 34th ed., pp. 33-47. London: Longmans.

Deo, M. G., Sood, S. K. \& Ramalingaswami, V. (1965). Arch. Path. 80, 14.

Dickerson, J. W. T. \& John, P. M. V. (1969). Br. J. Nutr. 23, 917.

Doumas, B. T., Watson, W. A. \& Biggs, H. G. (1971). Clinica chim. Acta 31, 87.

Dziewiatkowski, D. D. (1951). J. exp. Med. 93, 451.

Dziewiatkowski, D. D. (1954). J. exp. Med. 99, 283.

Dziewiatkowski, D. D. (1964). Connective Tissue: Intercellular Macromolecules, 1st ed., pp. 215-238. Boston, Mass.: Little Brown \& Co.

Dziewiatkowski, D. D., DiFerrante, N., Bronner, F. \& Okinaka, G. (1957). J. exp. Med. 106, 501.

Engfeldt, B. \& Hjertquist, S. O. (1967). Acta Path. Microbiol. scand. 71, 219.

Evans, H. M., Simpson, M. E., Marx, W. \& Kibrick, E. (1943). Endocrinology 32, 13.

Freud, J., Levie, L. H. \& Kroon, D. B. (1939). J. Endocr. 1, 56.

Grant, D. B., Hambley, J., Becker, D. \& Pimstone, B. L. (1973). Archs Dis. Childh. 45, 596,

Greenspan, F. S., Li, C. H., Simpson, M. E. \& Evans, H. M. (1949). Endocrinology 45, 455.

Harper, A. E. (1959). J. Nutr. 68, 405.

Hazlewood, C. F. \& Nichols, B. L. (1969). Bull. Johns Hopkins' Hosp. 125, 119.

Higginson, J. (1954). Metabolism 3, 392.

Ingalls, T. H. \& Hayes, D. R. (1941). Endocrinology 29, 720.

Jha, G. J., Deo, M. G. \& Ramalingaswami, V. (1968). Am. J. Path. 53, 111.

Kalk, W. J. \& Pimstone, B. L. (1974). Br. J. Nutr. 32, 569.

le Roith, D. \& Pimstone, B. L. (1973). Clin. Sci. 44, 305. 
Lillie, R. D. \& Ashburn, L. L. (1943). Arch. Path. 36, 432.

Lowry, O. H., Rosebrough, N. J., Farr, A. L. \& Randall, R. J. (1951). J. biol. Chem. $193,265$.

Phillips, L. S. \& Young, H. S. (1976). Endocrinology 99, 304.

Platt, B. S. \& Stewart, R. J. C. (1962). Br. J. Nutr. 16, 483.

Quintarelli, G., Scott, J. E. \& Dellovo, M. C. (1964). Histochemie 4, 86.

Ray, R. D., Evans, H. M. \& Becks, H. (1941). Am. J. Path. 17, 509.

Salmon, W. D. \& Daughaday, W. H. (1957). J. Lab. clin. Med. 49, 825.

Silberberg, M. \& Silberberg, R. (1940). Arch. Path. 30, 675.

Stead, R. H. \& Brock, J. F. (1972). J. Nutr. 102, 1357.

Sweet, M. B. E. (1968). Stain Tech. 43, 79.

Trowell, H. C., Davies, J. N. P. \& Dean, R. F. A. (1954). Kwashiorkor. London: Edward Arnold Ltd.

Weinkove C., Weinkove, E. A. \& Pimstone, B. L. (1976). Clin. Sci. mol. Med. 50, 153. 